\title{
BÖLGESEL KALKINMADA DIŞ TİCARETINN ROLÜ: TR81 BÖLGESİ ÖRNEĞİ
}

\author{
Yrd. Doç. Dr. Dilek ŞAHİN ${ }^{1}$ \\ Cumhuriyet Üniversitesi, Turizm Fakültesi, (dilek58sahin@hotmail.com)
}

\begin{abstract}
ÖZET
Dış ticaret bölgesel kalkınmanın gerçekleştirilmesinde önemli bir role sahiptir. Artan ihracat sayesinde bölgesel üretim artmakta ve ekonomik büyüme gerçekleşmektedir. TR81, Zonguldak, Karabük ve Bartın illerini kapsayan bir Düzey-2 Bölgesidir. Bu çalışmada, ilk olarak TR81 bölgesinin ekonomik görünümü ortaya konulmuştur. Daha sonra, bölgenin dış ticaret yapısı analiz edilmiştir. Bu kapsamda, çalışmada 2010-2016 dönemi verileri kullanılarak bölgenin ticaret hacmi, dış ticaretin sektörel bileşimi ve ticaret yaptığı ülkeler hakkında bilgi verilmiştir.
\end{abstract}

Anahtar Kelimeler: Bölgesel Kalkınma, Dış Ticaret, Endüstri içi Ticaret, TR81 Bölgesi.

\section{THE ROLE OF FOREIGN TRADE IN REGIONAL DEVELOPMENT: TR81 REGION SAMPLE}

\begin{abstract}
Foreign trade plays an important role in the realization of regional development. Thanks to increased exports regional production is increasing and economic growth is taking place. TR81; is a Level-2 region covering Zonguldak, Karabük and Bartın. In this study, firstly the economic view of the TR81 region was revealed. Then, foreign trade structure of the region were analyzed. In this context, it was about informed the trade volume of the region, the sectoral composition of foreign trade and the countries that is trades with using the 2010-2016 period data.
\end{abstract}

Keywords: Regional Development, Foreign Trade, Intra-Industry Trade, TR81 Region.

\footnotetext{
${ }^{1}$ Sorumlu Yazar/ Correspoding Author
} 


\section{Giriş}

Kalkınma kavramı, bir toplumda ekonomik, toplumsal ve siyasal alanda arzu edilen her türlü değişme ve gelişme olarak ifade edilmektedir (Tüylüoğlu \& Çeştepe, 2004: 29). Başka bir ifadeyle kalkınma milli gelir artışı yanı sıra ekonomik ve sosyal yapıda ortaya çıkan dönüşümdür. Bölgesel kalkınma ise, bir bölgenin sosyoekonomik ve demografik göstergelerinin, iş olanaklarının, yaşam standardının ve bölgede yaşayan insanların yaşam kalitesinin artırılmasıdır. Kalkınma, ülkelerin iç dinamiklerine bağlı bir olgudur. Dış ticaret, bu dinamiklerin çalışmasında önemli bir rol üstlenmektedir. Küreselleşen dünyada dış ticaretin katkısı olmadan kalkınmanın sağlanamayacağı genel kabul görmektedir. Özellikle azgelişmiş ülkeler, ekonomik kalkınmaları için gerekli olan sanayi ve yatırım mallarını, ihracat karşılığında elde ettikleri gelir ile ithal ederek sağlayabilir. Başka bir ifadeyle kalkınma yatırımlarının finansmanı için ihracattan elde edilen gelirler oldukça önemlidir ve yüksek kalkınma hızına ulaşabilmek için ihracat gelirlerinin artırılması gerekmektedir.

İhracat ve bölgesel kalkınma ilişkisinin teorik temelleri, ihracat tabanlı teorilere dayanmaktadır. Bu teorilere göre, ihracat yapan sanayiler bölgesel gelişmede önemli rol üstlenmektedir. Ayrıca bölgenin ekonomik büyümesinde bölgenin ihracattan elde ettiği başarı oldukça önemlidir (Eren, 2016: 468). İhracat tabanlı teoriye göre, ihracatın bölgesel kalkınma üzerine etkilerini şu şekilde sıralamak mümkündür (Brazzeland ve Hicks, 1968: 503-509):

- İhracattaki artış, ihracat yapan endüstrilerin ara mal ve hizmet faktörü ihtiyacını artırarak gelir artışını sağlamaktadır. Gelirde ortaya çıkan artış hane halkının tüketimini artırmakta böylelikle bölgenin toplam katma değerinde artış ortaya çıkar.

- İhracattaki artış kaynakları nitelik ve nicelik olarak artırır. Böylelikle yerli ve ithal ürünlere olan talepte artacağından teknolojik gelişmeler ortaya çıkar.

- İhracatın artması işgücünün niceliğini ve niteliğini artırır. Bölge geliştikçe bölgeye olan işgücü göçü artacaktır. İhracat üretimi uzmanlaşmış işgücüne ihtiyacı artırır.

- İhracat üretimindeki artış, sosyal sermaye için kamu harcamalarına yol açabilir.

- İhracattaki arış, bölgede daha gelişmiş yönetim ve üretim tekniklerinin benimsenmesini sağlar.

Şekil 1'de ihracat, ekonomik büyüme ve kalkınma döngüsü gösterilmiştir. Şekilden de anlaşılacağı üzere, ihracat artışı GSYH'nın artmasına olanak sağlayarak ekonomiyi iki yolla etkilemektedir. İlki, hanehalkı gelir artışını sağlayarak fakirlik oranını düşürmesidir. İkincisi ise, hükümet geliri ve harcamalarında artış sağlamasıdır. İlk etki doğrudan ortaya çıkarken; ikinci etki dolaylı bir şekilde ortaya çıkmaktadır. İhracat artışıyla birlikte üretim artarken hükümet artan üretimi vergilendirerek kendi gelirlerini artırır. Hanehalkının gelirlerinde ortaya çıkan artış, hanehalkının sosyal harcamalarında artışı sağlarken hanehalkının önceliklerinin değişmesine de olanak tanır. Ayrıca hanehalkı gelirinde ortaya çıkan artış, hanehalkı harcamalarının sosyal ve kalkınma harcamalarına yönelmesine; hükümet gelirlerindeki artışın ise eğitim, sağlık ve güvenlik gibi sosyal harcamalara yönelmesini sağlar. 
Şekil 1: İhracat, Ekonomik Büyüme ve Kalkınma Döngüsü

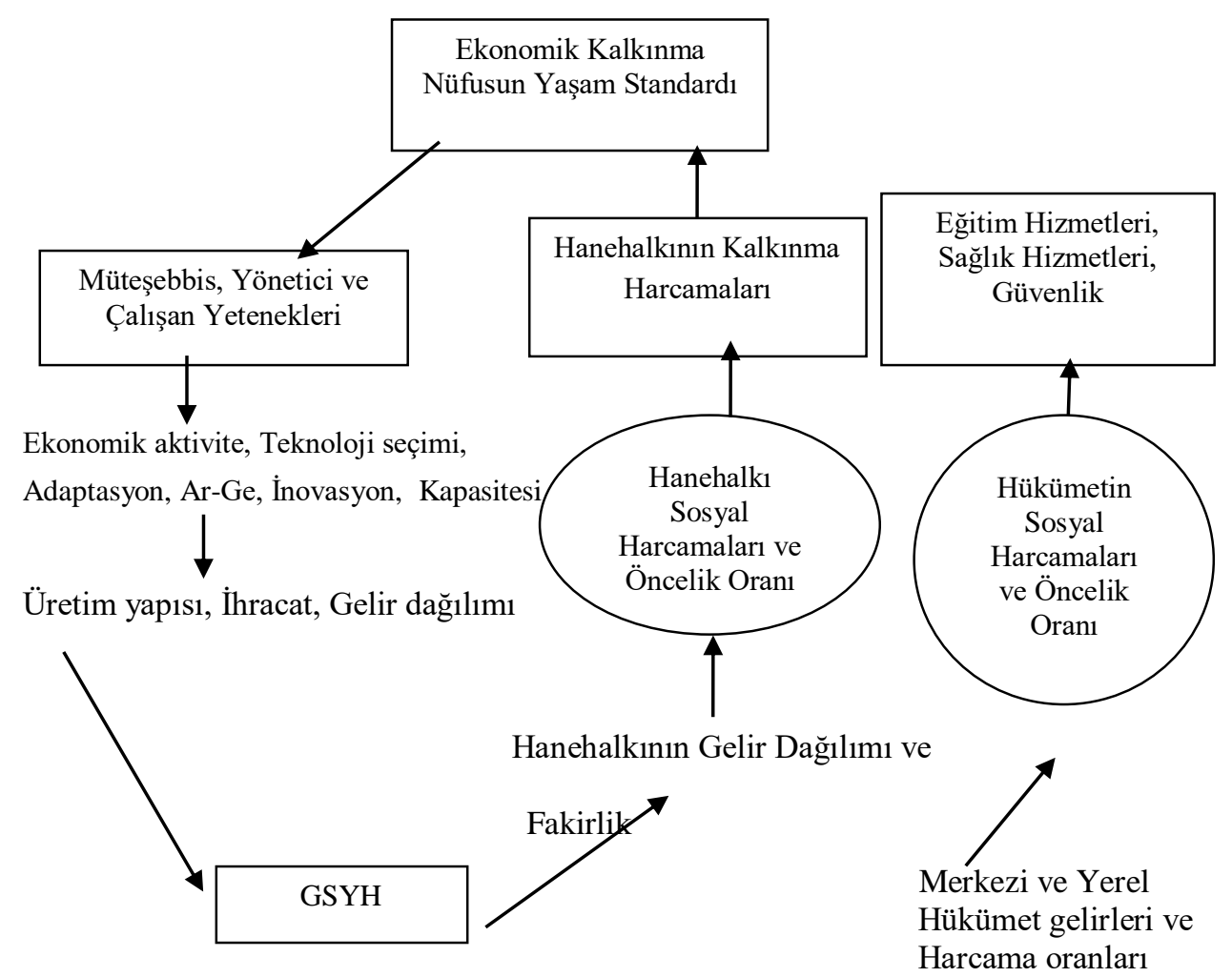

Kaynak: Poveda, 2011: 155.

Ülkemizde, bölgesel kalkınma politikalarının AB’nin bölgesel kalkınma politikalarına uyum sağlaması amacıyla 2002 yılında Bakanlar Kurulu kararı ile ülke çapında istatistiki Bölge Birimleri Sınıflandırması yapılmıştır. Yapılan sınıflandırmada Düzey-1 olarak 12 bölge; Düzey-2 olarak 26 bölge; Düzey-3 olarak da 81 bölge (il) belirlenmiştir. Düzey-2 İstatistiki Bölge Birimleri arasında yer alan TR81 Bölgesi; Bartın, Karabük ve Zonguldak illerini kapsamaktadır. Bu çalışmanın amacı, bölgesel kalkınma ve dış ticaret ilişkisini TR81 Bölgesi için analiz etmektir. Bu bağlamda çalışmada öncelikle, TR81 Bölgesinin ekonomik görünümü ortaya konulmuştur ardından Bölgenin sosyo-ekonomik gelişmişlik düzeyi hakkında bilgi verilmiştir. Çalışmada 2010-2016 dönemleri arasında Bölgenin dış ticareti ele alınmıştır. Bölgenin dış ticaretinin sektörel bileşimi hakkında bilgi verildikten sonra sektörler faktör kullanım yoğunluklarına göre hammadde yoğun, emek yoğun, sermaye yoğun ve farklılaştırılmış ve bilim bazlı sektörler olarak sınıflandırılmıştır. Yapılan sınıflandırmaya göre sektörlerin endüstri içi ticaret yapısı analiz edilmiştir.

\section{TR81 Bölgesinin Sosyo-Ekonomik Görünümü}

TR81 Bölgesi; Zonguldak, Karabük ve Bartın illerinden oluşan Batı Karadeniz Bölgesinde yer almaktadır. 9.493.04 km2 yüzölçümü ile Bölge, Türkiye yüzölçümünün \%1,21'ini oluşturmaktadır. Şekil 2'de Türkiye'nin İstatistiki Bölge Birimlerine göre sınıflandırılması gösterilmiştir.

\section{Şekil 2: Türkiye İstatistiki Bölge Birimleri Sınıflandırması Düzey-2}

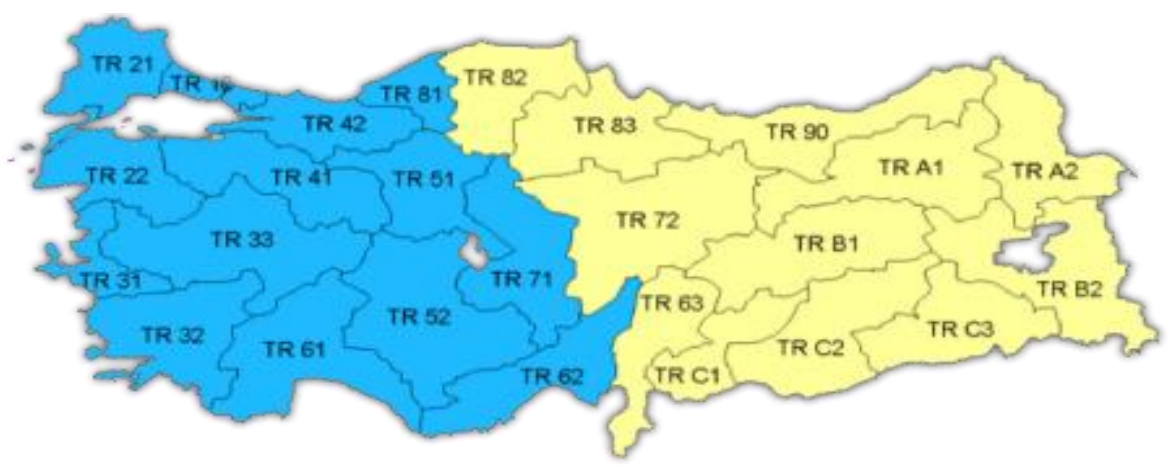


Tablo 1'de TR81 Bölgesinin nüfus potansiyeline yer verilmiştir. Tabloda görüldüğü üzere, TR81 bölgesi, 2016 yılında Türkiye nüfusunun \%1,29'ünü oluşturmaktadır. Bölgede, Zonguldak 597.524 kişi ile en yüksek nüfusa sahip ildir. Bölgede en düşük nüfusa sahip olan il 192.389 kişilik nüfusu ile Bartın'dır.

Tablo 1: TR81 Bölgesinin Nüfus Potansiyeli

\begin{tabular}{|c|c|c|c|c|c|c|}
\hline Yıllar & Bartın & Karabük & Zonguldak & $\begin{array}{c}\text { TR81 } \\
\text { Nüfusu }\end{array}$ & Türkiye & TR81/Türkiye \\
\hline 2010 & 187.758 & 227.610 & 619.703 & 1.035 .071 & 73.722 .988 & 1,40 \\
\hline 2011 & 187.291 & 219.728 & 612.406 & 1.019 .425 & 74.724 .269 & 1,36 \\
\hline 2012 & 188.436 & 225.145 & 606.527 & 1.020 .108 & 75.627 .384 & 1,34 \\
\hline 2013 & 189.139 & 230.251 & 601.567 & 1.020 .957 & 76.667 .864 & 1,33 \\
\hline 2014 & 189.405 & 231.333 & 598.796 & 1.019 .534 & 77.695 .904 & 1,31 \\
\hline 2015 & 190.708 & 236.978 & 595.907 & 1.023 .593 & 78.741 .053 & 1,29 \\
\hline 2016 & 192.389 & 242.347 & 597.524 & 1.032 .260 & 79.814 .871 & 1,29 \\
\hline
\end{tabular}

Kaynak: TÜİK.

Tablo 2'de Bölgenin 15-64 yaş aralığı için işgücü piyasasına ait verilere yer verilmiştir. Tabloda görüldüğü üzere, 2016 yılında bölgede işsizlik oranı \%9,1; işgücüne katılım oranı \%56,3; istihdam oranı ise $\% 51,2$ oranında gerçekleşmiştir.

\section{Tablo 2: TR81 Bölgesinin İşgücü Durumu}

\begin{tabular}{|l|l|l|l|}
\hline Göstergeler & $\mathbf{2 0 1 4}$ & $\mathbf{2 0 1 5}$ & $\mathbf{2 0 1 6}$ \\
\hline İşsizlik Oranı (\%) & 6,3 & 7,4 & 9,1 \\
\hline İşücüne Katılım Oranı (\%) & 57 & 56,8 & 56,3 \\
\hline İstihdam Oranı (\%) & 53,4 & 52,6 & 51,2 \\
\hline
\end{tabular}

Kaynak: TÜİK. Not: (15-64) nüfus işgücü rakamları alınmıştır.

İstihdamın sektörel dağılımı, toplumların gelişmişlik seviyesi hakkında bilgi veren önemli göstergelerden birisidir. Ekonomik gelişmişlik seviyesi arttıkça istihdamın tarımdan hizmetler sektörüne doğru kayması beklenmektedir. Şekil 3' de TR81 bölgesinde istihdamın sektörel dağılımı gösterilmiştir. İstihdamın sektörel dağılımına bakıldığında, 2010 yılında istihdamın \%40,63'ü tarım sektöründe; \%23,21'i sanayi sektöründe \%36,14'ü ise hizmetler sektöründe istihdam edilmektedir. 2016 yılına gelindiğinde istihdamın \%32,24'ü tarım sektöründe \%23,77'si sanayi sektöründe \%43,98'i hizmetler sektöründe istihdam edilmektedir. Bölgede 20102016 yılları arasında, tarım sektöründe istihdamda az da olsa bir azalış olmasına rağmen sektörün bölgedeki ağırlığı devam etmektedir.

\section{Şekil 3: TR81 Bölgesinde İstihdamın Sektörel Dağılımı}

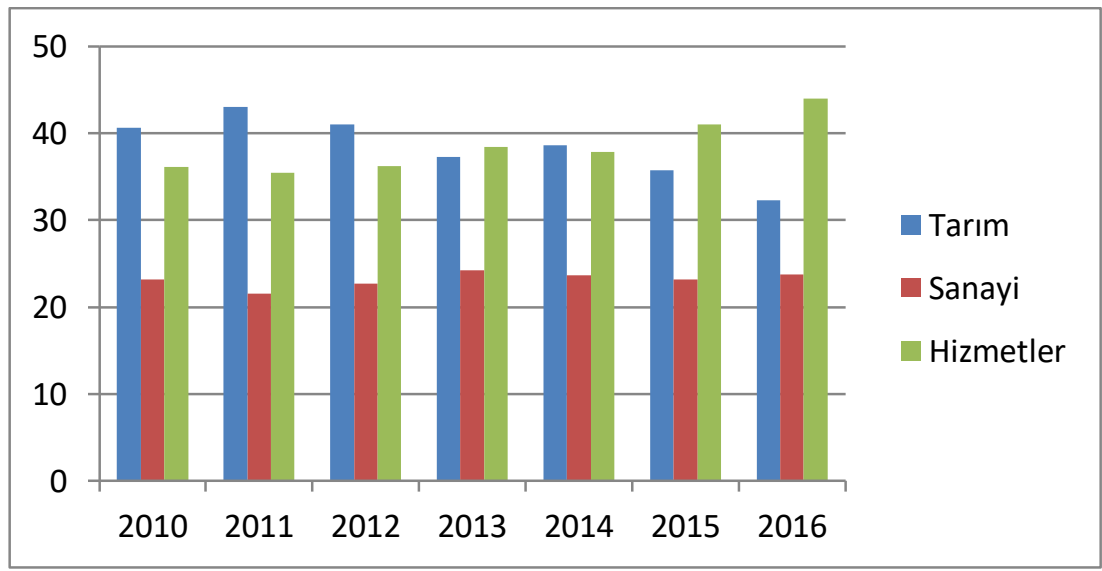

Kaynak: TÜIK.

Bölgelerin sosyo-ekonomik gelişmişlik düzeyinin tespitinde bölgenin gayrisafi katma değerin tespiti oldukça önemlidir. Bir bölgenin üretim gücünü gösteren önemli göstergelerden biri de bölgesel gayrisafi katma değerdir. Bölgesel gayrisafi katma değer (GSKD), bir bölgedeki yerleşik ekonomik birimlerin belirli bir dönemde, bu bölgedeki ekonomik faaliyetleri neticesinde ürettikleri mal ve hizmetlerin değerinden bu üretimde 
bulunabilmek için kullandıkları mal ve hizmetler değerinin çıkarılmasıyla elde edilir. Bölgesel gayrisafi katma değer ile bölgede ikamet eden üreticilerin ekonomik faaliyetlerinin ölçülmesi hedeflenmektedir. Gayrisafi katma değer tahminlerinin bölgesel gayrisafi yurt içi hâsıla tahminlerinden temel farkı, KDV ve ÖTV gibi ürün üzerinde bulunan vergileri içermemesidir. Ayrıca bölgesel GSKD hesapları dolaylı ölçülen mali aracılık hizmetlerinin ara tüketime giden kısmını da içermektedir (TÜíK, 2014:2). Şekil 4'de Türkiye ve TR81 Bölgesinin gayrisafi katma değeri görülmektedir. Gayrisafi katma değer miktarında istikrarlı bir artış, bölgenin gelişme seviyesi hakkında bilgi vermektedir. 2007 yılında TR81 Bölgesi 26 Düzey-2 Bölgesi içerisinde 8.sırada yer alırken; 2011 yılına gelindiğinde 10.sırada yer almaktadır. TR81 Bölgesinin Türkiye gayrisafi katma değerine katkısında 2007 yılından 2011 yılına kadar önemli bir değişiklik olmadığı görülmektedir.

Şekil 4: Türkiye ve TR81 Bölgesi Kişi Başına Gayrisafi Katma Değer (dolar)

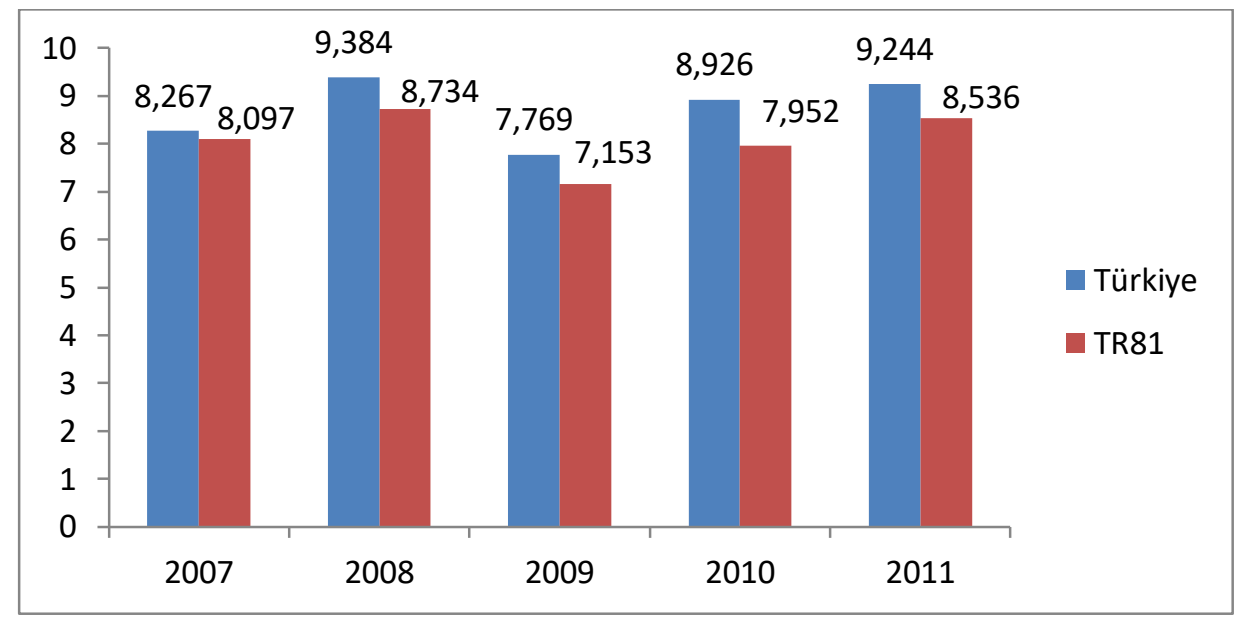

Kaynak: TÜİK. Not: veriler en son 2011 yılına kadar mevcuttur.

Şekil 5'te TR81 Bölgesinde sektörlerin gayrisafi katma değer içindeki \% payı gösterilmektedir. 2007 yılında TR81 Bölgesinin gayrisafi katma değeri içinde tarım sektörünün payının \%5,7; sanayi sektörünün payının \%39,6; ve hizmetler sektörünün payının da \%54,7 olduğu görülmektedir. 2011 yılına gelindiğinde tarım sektörünün payının \%6; sanayi sektörünün payının \%39,7 ve hizmetler sektörünün payının da \%54,3 olduğu görülmektedir.

\section{Şekil 5: TR81 Bölgesinde Sektörlerin Gayrisafi Katma Değer İçindeki \% Payı}

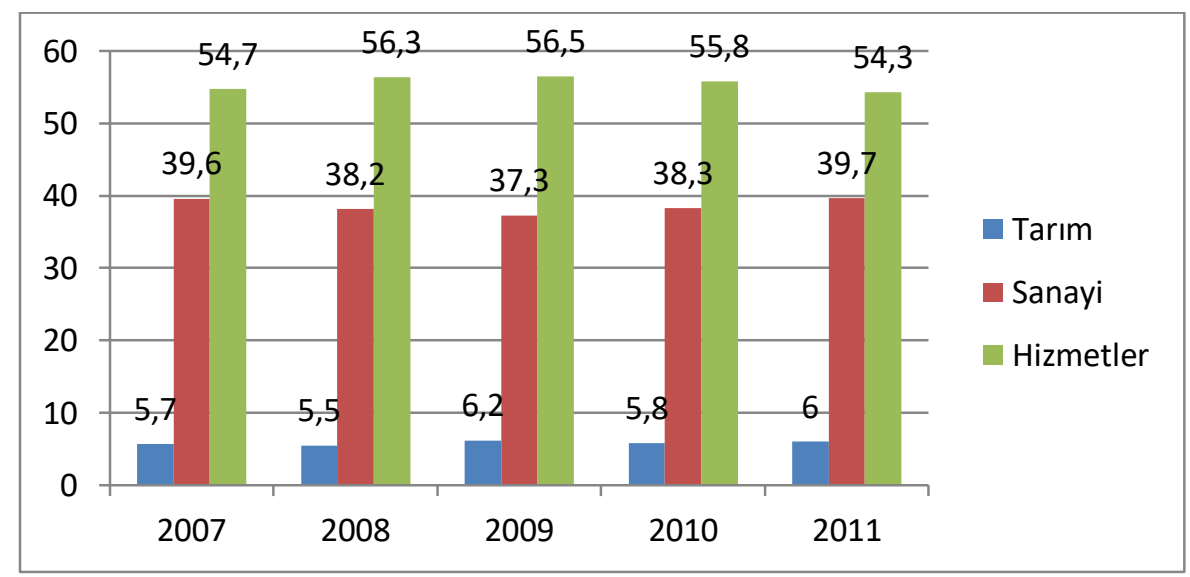

Kaynak: TÜIK. Not: veriler en son 2011 yılına kadar mevcuttur.

Şekil 6'da ise, Türkiye ve TR81 Bölgesinde, sektörlerin gayrisafi katma değer içindeki \% payına yer verilmiştir. 2007 yılında gayrisafi katma değer içindeki tarım sektörünün payının \% $\%$,5; sanayi sektörünün payının \%27,8; ve hizmetler sektörünün payının da \%63,7 olduğu görülmektedir. 2011 yılına gelindiğinde ise tarım sektörünün payının \% 9; sanayi sektörünün payının \%27,5; ve hizmetler sektörünün payının da $\% 63,5$ olduğu görülmektedir. TR81 Bölgesinde tarım sektörünün gayrisafi katma değer içindeki payının Türkiye ortalamasının altında seyrettiği görülmektedir. Ayrıca sanayi sektörünün gayrisafi katma değere olan katkısının Türkiye ortalamasının üzerinde olduğu gözlenmektedir. Hizmetler sektörünün ise Türkiye ortalamasının altında olduğu 
dikkat çekmektedir. Ayrıca TRB1 Bölgesinde sektörel paylar sıralamasının Türkiye ile paralellik gösterdiği ve hizmetler sektörünü sırasıyla sanayi ve tarım sektörünün izlediği görülmektedir.

\section{Şekil 6: Türkiye ve TR81 Bölgesinde Sektörlerin Gayrisafi Katma Değer İçindeki \% Payı}

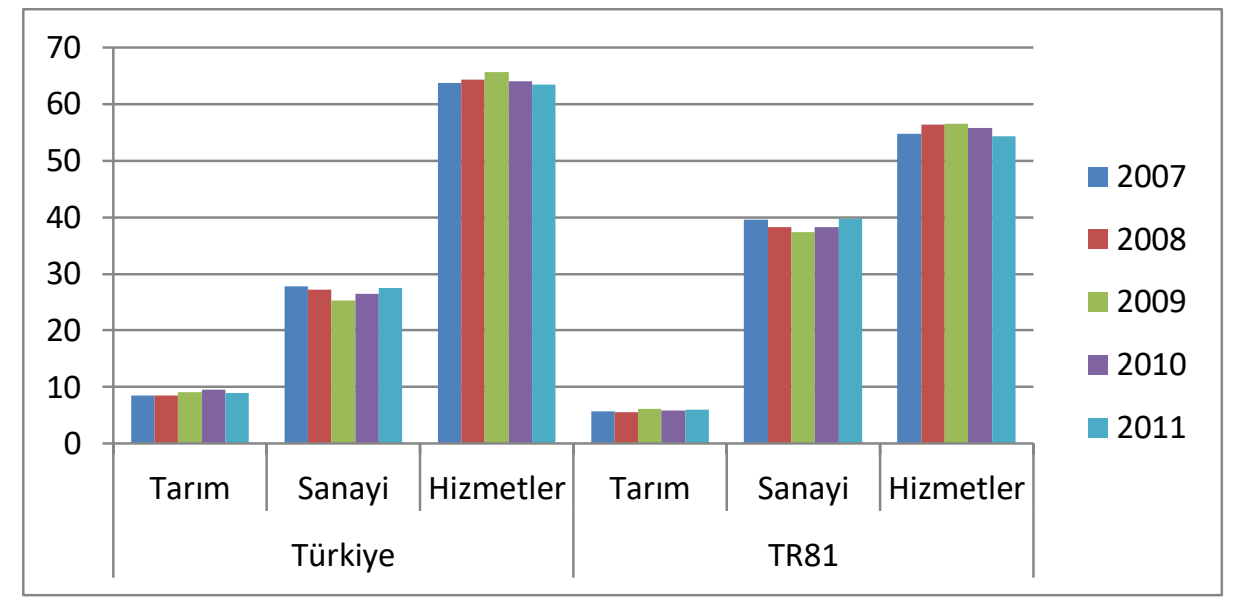

Kaynak: TÜIKK. Not: veriler en son 2011 yılına kadar mevcuttur.

Şekil 7'de Türkiye ve TR81 Bölgesinin kişi başına GSYH büyüme oranı verilmiştir. Sosyo-ekonomik gelişmişlik düzeyinin en önemli göstergelerinden biri olan GSYH değerleri, en son 2001 yılında TÜỉK tarafindan yayınlanmıştır. Milli gelir hesaplamalarında gerçekleşen son gelişmelerin, GSYH değerlerine göre yapılan bölge sıralamalarını çok fazla etkilemeyeceği varsayımıyla; Şekil 6'da görüldüğü üzere bölge illerinden Bartın ve Karabük'ün 2001 yılında kişi başına GSYH miktarlarının 2.146 dolar olan Türkiye ortalamasının altında gerçekleşmiştir. Zonguldak'ın ise kişi başına GSYH miktarlarının 2.146 dolar olan Türkiye ortalamasının üstünde gerçekleştiği görülmektedir.

\section{Şekil 7: 2001 Yılı Türkiye ve TR81 Bölgesi Kişi başına GSYH Büyüme Oranı (dolar)}

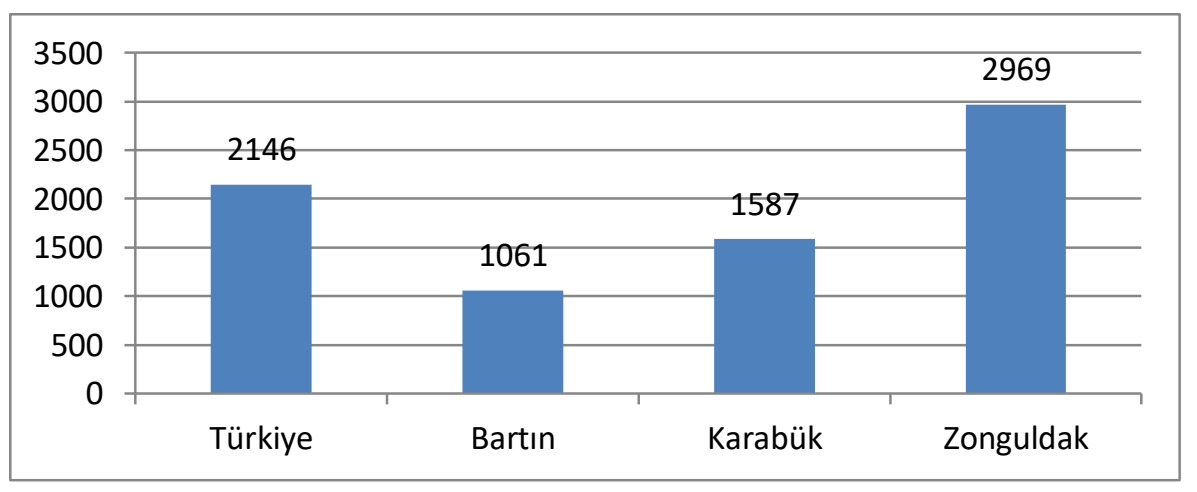

Kaynak: TÜIK

Bölgelerin rekabet güçlerinin rakiplerine göre artırılabilmesi için öncelikle rekabet edebilirlik seviyelerinin ölçülmesi ve belirlenmesi gerekir. Bölgelerin rekabet güçlerinin tespitinde Uluslararası Rekabet Araştırmaları Kurulu (URAK) tarafindan "beşeri sermaye, yenilikçilik, üretim ve ticaret değişkeni ve yaşanabilirlik" olarak dört ana gösterge kullanılmaktadır. Beşeri sermaye değişkeni hesaplanırken; mesleki ve teknik okul mezun sayısı, ilin YGS başarı yüzdesi, ildeki bir yüksek öğrenim programından (önlisans, lisans) mezun olan öğrenci sayısı, ildeki öğretim üyesi başına düşen üniversite öğrencisi sayısı vb. değişkenler kullanırken; yenilikçilik değişkeni hesaplanırken; ilde bulunan Ar-Ge merkezi sayısı, ilin teknolojik ürün ihracatı, ilde bulunan teknoloji geliştirme merkezi sayısı ile ait 100.000 kişi başına düşen patent başvuru sayısı vb. değişkenler; üretim ve ticaret değişkeni hesaplanırken; ilin ihracat hacmi, ihracat yapan firma sayısı, yaşanabilirlik değişkeni hesaplanırken; ilin net göç hızı, şehirleşme oranı, kişi başına düşen uzman hekim sayısı, ilin hava kalitesi değeri, ildeki kaba boşanma hızı, ildeki otoyol uzunluğu, haberleşme-ulaştırma alanında kamu yatırımı, bebek ölüm hızı vb. değişkenler kullanılmaktadır. 
Tablo 3'de, TR81 Bölgesi illerinin rekabetçilik endeksi sıralaması gösterilmiştir. TR81 Bölgesinin kendi içinde gerek gelişmişlik düzeyi bakımından gerekse öne çıkan sektörler bakımından heterojen bir yapıya sahip olduğu görülmektedir. $\mathrm{Bu}$ sıralama neticesinde Bölgenin rekabet seviyesi düşük ilinin Bartın olduğu görülmektedir. Karabük ve Zonguldak'ın rekabet seviyesi ise birbirine yakındır.

Tablo 3: TRB1 Bölgesi Rekabetçilik Endeks Sırası

\begin{tabular}{|c|c|c|c|c|}
\hline İl & $\begin{array}{c}\text { 2010-2011 Genel } \\
\text { Endeks Sirası }\end{array}$ & $\begin{array}{c}\text { 2011-2012 Genel } \\
\text { Endeks Sirası }\end{array}$ & $\begin{array}{c}\text { 2012-2013 Genel } \\
\text { Endeks Sirası }\end{array}$ & $\begin{array}{c}\mathbf{2 0 1 3 - 2 0 1 4} \\
\text { Genel Endeks } \\
\text { Sirası }\end{array}$ \\
\hline Bartın & 59 & 55 & 54 & 59 \\
\hline Karabük & 44 & 29 & 38 & 29 \\
\hline Zonguldak & 34 & 38 & 39 & 36 \\
\hline
\end{tabular}

Kaynak: URAK, 2016.

Tablo 4'de TR81 Bölgesinde rekabet gücü 2013-2014 dönemi için alt başlıklar itibariyle incelenmiştir. Buna göre; beşeri sermaye; üretim ve ticaret açısından Zonguldak ilinin; yenilikçilik ve yaşanabilirlik açısından Karabük ilinin ön sirada olduğu görülmektedir.

Tablo 4:TR81 Bölgesinde Alt Bileșenlere Göre Rekabetçilik Endeksi

\begin{tabular}{|c|c|c|c|c|}
\hline \multicolumn{5}{|c|}{$\begin{array}{c}\text { 2013-2014 } \\
\text { Genel Endeks Sırası }\end{array}$} \\
\hline İller & Beşeri Sermaye & Yenilikçilik & Üretim ve Ticaret & Yaşanabilirlik \\
\hline Bartın & 28 & 61 & 51 & 55 \\
\hline Karabük & 24 & 36 & 32 & 18 \\
\hline Zonguldak & 21 & 48 & 24 & 35 \\
\hline
\end{tabular}

Kaynak: URAK, 2016.

\section{TR81 Bölgesi Dış Ticaret Yapısı}

Tablo 5'de TR81 Bölgesinin dış ticaret yapısı ele alınmıştır. TR81 bölgesi 2010 yılı itibariyle 443.517.591 dolar düzeyinde ihracat; 1.869.103.310 dolar düzeyinde ithalat yapmaktadır. 2016 yılına gelindiğinde 499.883.494 dolar düzeyinde ihracat; 1.226.178.663 dolar düzeyinde ithalat yapılmaktadır.

\section{Tablo 5:TR81 Bölgesinde Yer Alan İllerin Dış Ticaret Hacmi}

\begin{tabular}{|c|c|c|c|c|c|c|c|c|}
\hline \multirow{2}{*}{ Yll } & \multicolumn{2}{|l|}{ Bartın } & \multicolumn{2}{|l|}{ Karabük } & \multicolumn{2}{|l|}{ Zonguldak } & \multirow{2}{*}{$\begin{array}{l}\text { TR81 } \\
\text { İhracat }\end{array}$} & \multirow[t]{2}{*}{ TR81 İthalat } \\
\hline & İhracat & İthalat & İhracat & İthalat & İhracat & İthalat & & \\
\hline 2010 & 15.693 .592 & 9.357 .576 & 139.790 .398 & 319.190 .704 & 288.033 .601 & 1.540 .555 .030 & 443.517 .591 & 1.869 .103 .310 \\
\hline 2011 & 20.625 .171 & 14.849 .982 & 224.019 .826 & 417.981 .994 & 435.569 .612 & 1.538 .101 .150 & 680.214 .609 & 1.970 .933 .126 \\
\hline 2012 & 14.116 .464 & 15.210 .926 & 167.424 .439 & 482.827 .237 & 321.157 .964 & 1.256 .296 .453 & 502.698 .867 & 1.754 .334 .616 \\
\hline 2013 & 20.313 .666 & 8.957 .074 & 258.721 .667 & 492.643 .225 & 312.925 .328 & 1.349 .666 .825 & 591.960 .661 & 1.851 .267 .124 \\
\hline 2014 & 11.176 .056 & 9.324 .932 & 296.650 .550 & 551.628 .474 & 425.330 .291 & 1.258 .809 .298 & 733.156 .897 & 1.819 .762 .704 \\
\hline 2015 & 9.569 .975 & 11.907 .850 & 214.944 .866 & 520.437 .557 & 201.749 .106 & 995.471 .424 & 426.263 .947 & 1.527 .816 .831 \\
\hline 2016 & 13.805 .911 & 12.137 .319 & 245.162 .522 & 456.295 .423 & 240.915 .061 & 757.745 .921 & 499.883 .494 & 1.226 .178 .663 \\
\hline
\end{tabular}

Kaynak: TÜİK. Not. ISIC Rev.3, 2 haneli sınıflandırma kullanılmıştır.

Tablo 6'da TR81 Bölgesinde yer alan illerin bölge ticaretindeki payları gösterilmiştir. Buna göre, bölge ihracatında ve ithalatın en yüksek pay Zonguldak iline aittir. Zonguldak’1 Karabük ili takip etmektedir. Bölgede ticaretin en az olduğu il ise Bartın’dır. 
Tablo 6: TR81 Bölgesinde Yer Alan İllerin Bölge Ticaretindeki \% Payı

\begin{tabular}{|c|c|c|c|c|c|c|}
\hline \multirow{2}{*}{ Yıl } & \multicolumn{2}{|c|}{ Bartın } & \multicolumn{2}{c|}{ Karabük } & \multicolumn{2}{c|}{ Zonguldak } \\
\cline { 2 - 7 } & İhracat & İthalat & İhracat & Ithalat & Ihracat & İthalat \\
\hline $\mathbf{2 0 1 0}$ & 3,53 & 0,50 & 31,51 & 17,07 & 64,94 & 82,42 \\
\hline $\mathbf{2 0 1 1}$ & 3,03 & 0,75 & 32,93 & 21,20 & 64,03 & 78,03 \\
\hline $\mathbf{2 0 1 2}$ & 2,80 & 0,86 & 33,30 & 27,52 & 63,88 & 71,61 \\
\hline $\mathbf{2 0 1 3}$ & 3,90 & 0,48 & 43,70 & 26,61 & 52,86 & 72,90 \\
\hline $\mathbf{2 0 1 4}$ & 1,52 & 0,51 & 40,46 & 30,31 & 58,01 & 69,17 \\
\hline $\mathbf{2 0 1 5}$ & 2,24 & 0,77 & 50,42 & 34,06 & 47,32 & 65,15 \\
\hline $\mathbf{2 0 1 6}$ & 2,76 & 0,98 & 49,04 & 37,21 & 48,19 & 61,79 \\
\hline
\end{tabular}

Kaynak: TÜİK verilerinden yola çıkılarak tarafımızca hesaplanarak düzenlenmiştir.

Tablo 7'de TR81 Bölgesinin en fazla ihracat ve ithalat yaptığı ilk 5 ülkeye yer verilmiştir. Buna göre, TRB1 Bölgesinin en fazla ihracat yaptığı ülkeler arasında Romanya, İspanya, İngiltere, Almanya, ABD yer alırken; en fazla ithalat yaptığı ülkeler arasında Ukrayna, Rusya, İsveç ve Brezilya yer almaktadır.

Tablo 7: TR81 Bölgesinin En Fazla İhracat ve İthalat Yaptığı İlk 5 Ülke

\begin{tabular}{|c|c|c|}
\hline Yll & İhracat & İthalat \\
\hline $\mathbf{2 0 1 0}$ & Romanya, İspanya, İngiltere, Almanya, İtalya & ABD, İsveç, Ukrayna, Belarus, Brezilya \\
\hline $\mathbf{2 0 1 1}$ & Romanya, Fas, İtalya, Belçika, İspanya & İsveç, ABD, Ukrayna, Rusya, Brezilya \\
\hline $\mathbf{2 0 1 2}$ & Romanya, ABD, Fas, İngiltere, Almanya & Ukrayna, ABD, Brezilya, Rusya, İsveç \\
\hline $\mathbf{2 0 1 3}$ & ABD, Romanya, Fas, Almanya, İngiltere & Ukrayna, Rusya, ABD, İsveç, Brezilya \\
\hline $\mathbf{2 0 1 4}$ & ABD, Fas, Romanya, Kanada, Almanya & Ukrayna, Rusya, ABD, Brezilya, İngiltere \\
\hline $\mathbf{2 0 1 5}$ & Fas, Romanya, ABD, Almanya, İngiltere & Rusya, Ukrayna, Brezilya, ABD, İsveç \\
\hline $\mathbf{2 0 1 6}$ & ABD, Romanya, Fas, İran, Almanya & Rusya, Ukrayna, Avustralya, İsveç, Brezilya \\
\hline
\end{tabular}

Kaynak: TÜİK

Tablo 8'de TR81 Bölgesinde yer alan illerin en fazla ihracat yaptığı ülkeler bulunmaktadır. Buna göre, Bartın ili Almanya ile; Karabük ili Fas ile; Zonguldak ili ise Romanya ile ihracat yapmaktadır.

Tablo 8: TR81 Bölgesinde Yer Alan İllerin En Fazla İhracat Yaptı̆̆ı Ülkeler (dolar)

\begin{tabular}{|c|c|c|c|c|c|c|}
\hline \multirow{2}{*}{ Yıl } & \multicolumn{2}{|c|}{ Bartın } & \multicolumn{2}{c|}{ Karabük } & \multicolumn{2}{c|}{ Zonguldak } \\
\cline { 2 - 7 } & Ülke & Dĕger & Ülke & Dĕger & Ülke & Değer \\
\hline $\mathbf{2 0 1 0}$ & Almanya & 10.335 .291 & Suriye & 31.621 .220 & Romanya & 43.578 .249 \\
\hline $\mathbf{2 0 1 1}$ & Almanya & 14.730 .739 & Fas & 39.242 .505 & Romanya & 63.616 .913 \\
\hline $\mathbf{2 0 1 2}$ & Almanya & 7.830 .162 & Fas & 43.860 .209 & Romanya & 60.387 .093 \\
\hline $\mathbf{2 0 1 3}$ & Almanya & 12.841 .628 & Fas & 39.848 .182 & Romanya & 39.470 .702 \\
\hline $\mathbf{2 0 1 4}$ & Almanya & 4.621 .435 & Fas & 74.170 .136 & ABD & 113.398 .894 \\
\hline $\mathbf{2 0 1 5}$ & Almanya & 3.320 .749 & Fas & 53.875 .057 & Romanya & 36.437 .111 \\
\hline $\mathbf{2 0 1 6}$ & Almanya & 6.926 .476 & Fas & 43.882 .452 & ABD & 37.960 .330 \\
\hline
\end{tabular}

Kaynak: TÜİK 
Tablo 9'da TR81 Bölgesinde yer alan illerin en fazla ithalat yaptığ ülkeler bulunmaktadır. Buna göre, Bartın'ın Çin ve Almanya'dan; Karabük'ün Ukrayna'dan; Zonguldak'ın İsveç'ten ithalat yaptığg görülmektedir.

Tablo 9: TR81 Bölgesinde Yer Alan İllerin En Fazla İthalat Yaptığı Ülkeler

\begin{tabular}{|c|c|c|c|c|c|c|}
\hline \multirow{2}{*}{ Yıl } & \multicolumn{2}{|c|}{ Bartın } & \multicolumn{2}{c|}{ Karabük } & \multicolumn{2}{c|}{ Zonguldak } \\
\cline { 2 - 7 } & Ülke & Değer & Ülke & Değer & Ülke & Değer \\
\hline $\mathbf{2 0 1 0}$ & Çin & 4.998 .455 & Ukrayna & 93.616 .867 & İsveç & 239.021 .453 \\
\hline $\mathbf{2 0 1 1}$ & Hindistan & 4.216 .438 & Ukrayna & 118.346 .879 & İsveç & 315.713 .077 \\
\hline $\mathbf{2 0 1 2}$ & Çin & 3.535 .489 & Ukrayna & 139.194 .776 & Brezilya & 249.544 .500 \\
\hline $\mathbf{2 0 1 3}$ & Rusya & 1.618 .516 & Ukrayna & 176.606 .154 & Ukrayna & 237.601 .261 \\
\hline $\mathbf{2 0 1 4}$ & Almanya & 2.969 .500 & Ukrayna & 190.811 .645 & İveç & 227.974 .373 \\
\hline $\mathbf{2 0 1 5}$ & Almanya & 5.609 .726 & Ukrayna & 157.470 .300 & Avustralya & 71.600 .692 \\
\hline $\mathbf{2 0 1 6}$ & Çin & 3.847 .144 & Ukrayna & 139.100 .669 & Rusya & 130.930 .406 \\
\hline
\end{tabular}

Kaynak: TÜİK

Tablo 10'da TR81 Bölgesinin en fazla ihraç ve ithal ettiği 5 ürün yer almaktadır. Buna göre bölgenin en fazla ihraç edilen ürünler arasında; ana metal sanayi, metalik olmayan diğer mineral ürünler, başka yerde sınıflandırılmamış makine ve teçhizat, metal eşya sanayi (makine ve teçhizatı hariç), plastik ve kauçuk ürünleri bulunmaktadır. En fazla ithal edilen ürünler arasında ise; metal cevherleri, maden kömürü, linyit, ana metal sanayi, atık ve hurdalar, başka yerde sınıflandırılmamış makine ve teçhizat bulunmaktadır.

Tablo 10: TR81 Bölgesinin En Fazla İhraç ve İthal Ettiği 5 Ürün

\begin{tabular}{|c|c|c|}
\hline Yll & En Fazla İhraç Edilen Ürünler & En Fazla İthal Edilen Ürünler \\
\hline 2010-2016 & $\begin{array}{ll}\text { - } & \text { Ana Metal Sanayi } \\
\text { - } & \text { Metalik olmayan diğer mineral ürünler } \\
\text { - } & \text { Başka yerde sinıflandırılmamış makine ve } \\
\text { - } & \text { Meçhizat } \\
\text { - } & \text { hariç) } \\
\text { Plastik ve kauçuk ürünleri }\end{array}$ & $\begin{array}{l}\text { - Metal Cevherleri } \\
\text { - } \text { Maden kömürü, linyit } \\
\text { - Ana metal sanayi } \\
\text { - } \text { Başka ye hurdalar } \\
\\
\quad \text { sinıflandırılmamış makine } \\
\text { ve teçhizat }\end{array}$ \\
\hline
\end{tabular}

Kaynak: TÜİK. Not: Ürün sınıflandırmasında ISIC Rev.3 2 haneli sınıflandırma kullanılmıştır.

Tablo 11'de bölgede yer alan illerin en fazla ihraç ettiği ürünlere yer verilmiştir. Buna göre; Bartın ili, giyim eşyası, mobilya ve başka yerde sınıflandırılmamış diğer ürünler, tekstil ürünleri, plastik ve kauçuk ürünleri, metalik olmayan diğer mineraller; Karabük ili ana metal sanayi, başka yerde sınıflandırılmamış makine ve teçhizat, giyim eşyası, metalik olmayan diğer mineral ürünler; Zonguldak ili ana metal sanayi, metalik olmayan diğer mineral ürünler, metal eşya sanayi (makine ve teçhizatı hariç), plastik ve kauçuk ürünleri ihraç etmektedir.

Tablo 11: TR81 Bölgesinde Yer Alan İllerin En Fazla İhracat Yaptığı Ürünler

\begin{tabular}{|c|c|c|c|}
\hline Yll & Bartın & Karabük & Zonguldak \\
\hline $2010-2016$ & $\begin{array}{ll}\text { - } & \text { Giyim Eşyası } \\
\text { - } & \text { Mobilya ve başka } \\
& \text { yerde } \\
& \text { sinıflandırılmamış } \\
& \text { diğer ürünler } \\
\text { - } & \text { Tekstil ürünleri } \\
\text { - } & \text { Plastik ve kauçuk } \\
& \text { ürünleri } \\
\text { - } & \text { Metalik olmayan } \\
\text { diğer mineraller }\end{array}$ & 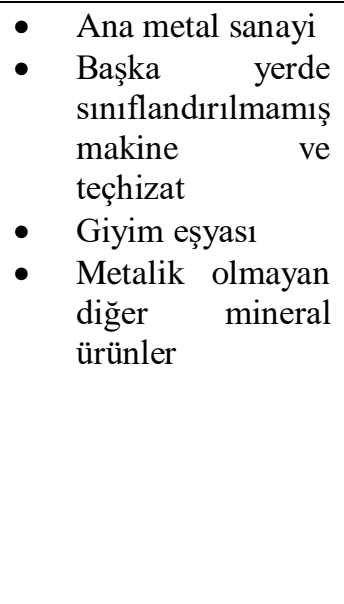 & $\begin{array}{ll}\text { - } & \text { Ana metal } \\
\text { sanayi } \\
\text { - } \\
\text { Metalik } \\
\text { olmayan } \\
\text { diğer } \\
\text { mineral } \\
\text { ürünler } \\
\text { - Metal eşya } \\
\text { sanayi } \\
\text { (makine ve } \\
\text { teçhizatı } \\
\text { hariç) } \\
\text { Plastik ve } \\
\text { kauçuk } \\
\text { ürünleri }\end{array}$ \\
\hline
\end{tabular}

Kaynak: TÜİK. Not: Ürün sınıflandırmasında ISIC Rev.3 2 haneli sınıflandırma kullanılmıştır. 
Tablo 12'de bölgede yer alan illerin en fazla ithal ettiği ürünlere yer verilmiştir. Buna göre; Bartın ili, tekstil ürünleri, kimyasal madde ve ürünler, ağaç ve mantar ürünleri (mobilya hariç) hasır vb. örülerek yapılan maddeler, başka yerde sınıflandırılmamış makine ve teçhizat ve tarım ve hayvancılık; Karabük ili, maden kömürü, linyit, ana metal sanayi, başka yerde sınıflandırılmamış makine ve teçhizat, metal cevherleri, kok kömürü, rafine edilmiş petrol ürünleri ve nükleer yakıtlar; Zonguldak ili metal cevheri, maden kömürü, linyit, ana metal sanayi, atık ve hurdalar ve başka yerde sınıflandırılmamış makine ve teçhizat ithal etmektedir.

Tablo 12: TR81 Bölgesinde Yer Alan İllerin En Fazla İthalat Yaptığı Ürünler

\begin{tabular}{|c|c|c|c|}
\hline Yil & Bartin & Karabük & Zonguldak \\
\hline 2010-2016 & $\begin{array}{ll}\text { - } & \text { Tekstil ürünleri } \\
\text { - Kimyasal madde ve } & \text { ürünler } \\
\text { - } & \text { Ağaç ve mantar ürünleri } \\
& \text { (mobilya hariç) hasır vb. } \\
& \text { örülerek yapılan } \\
& \text { maddeler } \\
\text { - } & \text { Başka yerde } \\
& \text { sinıflandırılmamış } \\
& \text { makine ve teçhizat } \\
\text { - Tarım ve hayvancılık }\end{array}$ & $\begin{array}{ll}\text { - } & \text { Maden kömürü, } \\
& \text { linyit } \\
\text { - } & \text { Ana metal sanayi } \\
\text { - } & \text { Başka yerde } \\
& \text { sinıflandırılmamış } \\
& \text { makine ve teçhizat } \\
\text { - } & \text { Metal cevherleri } \\
\text { - } & \text { Kok kömürü, rafine } \\
& \text { edilmiş petrol } \\
& \text { ürünleri ve nükleer } \\
\text { yakıtlar }\end{array}$ & $\begin{array}{ll}\text { - } & \text { Metal cevheri } \\
\text { - } & \text { Maden kömürü, } \\
& \text { linyit } \\
\text { - } & \text { Ana metal sanayi } \\
\text { - } & \text { Atık ve hurdalar } \\
\text { - } & \text { Başka yerde } \\
& \text { sinıflandırılmamış } \\
& \text { makine v ve } \\
\text { teçhizat }\end{array}$ \\
\hline
\end{tabular}

Kaynak: TÜIK. Not: Ürün sınıflandırmasında ISIC Rev.3 2 haneli sınıflandırma kullanılmıştır.

\section{TR81 Bölgesinin Dış Ticaret Yapısının Analizi}

Faktör kullanım yoğunluklarına göre imalat sanayi sektörlerini ISIC Rev.3'e göre "hammadde yoğun, ölçek yoğun, emek yoğun ve farklılaştırılmış ve bilim bazlı sektörler” alt başlıkları altında sınıflandırmak mümkündür. Bu sınıflandırma şu şekildedir:

Hammadde yoğun sanayiler: Gıda ürünleri ve içecek (15), tütün ürünleri (16), Ağaç ve Mantar Ürünleri (Mobilya hariç) (20), kok kömürü, Rafine Edilmiş Petrol ürünleri ve Nükleer yakıtlar (23), Metalik Olmayan Diğer Mineral Ürünler (26).

Ölçek yoğun Sanayiler: Kâğıt ve kâğı ürünleri (21), basım ve yayım; Plak, Kaset vb (22), Kimyasal madde ve ürünler (24), Plastik ve Kauçuk ürünleri (25), Ana metal sanayi (27), Motorlu Kara Taşıtı ve Römorklar (34), Diğer Ulaşım araçları (35).

Emek yoğun Sanayiler: Tekstil ürünleri (17), Giyim Eşyası (18), Dabaklanmış Deri, Bavul, El Çantası, Saraciye ve Ayakkabı (19), Metal Eşya Sanayi(Makine ve Teçhizat hariç) (28). Mobilya ve başka yerde sınıflandırılmamış diğer ürünler (36).

Farklılaştırılmış ve Bilim Bazlı Sanayiler: Başka yerde Sınıflandırılmamış makine ve Teçhizat (29),Büro muhasebe ve bilgi işleme makineleri (30), Başka yerde Sınıflandırılmamış Elektrikli Makine ve Cihazlar (31), Radyo-TV-Haberleşme Teçhizatı ve Cihazları (32), Tıbbi Aletler, Hassas Optik Aletler ve Saat (33).

Tablo 13'de faktör kulanım yoğunluklarına göre TR81 Bölgesi ihracatının toplam ihracat içindeki \% payına yer verilmiştir. Buna göre TR81 Bölgesinde ölçek yoğun sanayilerin ihracat içindeki payının diğer mal gruplarına göre fazla olduğu görülmektedir. Ayrıca hammadde yoğun sanayiler ile emek yoğun sanayilerin toplam ihracat içindeki paylarının birbirine yakın olduğu görülmektedir. İhracat içindeki en düşük pay ise farklılaştırılmış ve bilim bazlı sanayilerde gerçekleşmektedir. Bu durum şekil 8'de gösterilmiştir.

Tablo 13: Faktör Kullanım Yoğunluğuna Göre TRB1 Bölgesi İhracatının Toplam İhracat İçindeki \% Payı

\begin{tabular}{|c|c|c|c|c|c|c|c|c|}
\hline Yıl & \multicolumn{9}{|c|}{ TRB1 Bölgesi } \\
\hline $\begin{array}{c}\text { Faktör } \\
\text { Yoğunluğu }\end{array}$ & Sektör & $\mathbf{2 0 1 0}$ & $\mathbf{2 0 1 1}$ & $\mathbf{2 0 1 2}$ & $\mathbf{2 0 1 3}$ & $\mathbf{2 0 1 4}$ & $\mathbf{2 0 1 5}$ & $\mathbf{2 0 1 6}$ \\
\hline $\begin{array}{c}\text { Hammadde } \\
\text { yoğun sanayiler }\end{array}$ & $\mathbf{1 5}$ & 0,15 & 0,21 & 0,21 & 0,29 & 0,17 & 0,24 & 0,16 \\
\cline { 2 - 10 } & $\mathbf{1 6}$ & - & - & - & - & - & - & - \\
\cline { 2 - 10 } & $\mathbf{2 0}$ & 0,04 & 0,02 & 0,01 & 0,01 & 0,03 & 0,03 & 0,01 \\
\cline { 2 - 9 } & $\mathbf{2 3}$ & 0,13 & 0,06 & 0,16 & 0,12 & 0,41 & 0,44 & 1,40 \\
\cline { 2 - 9 } & $\mathbf{2 6}$ & 9,51 & 6,01 & 8,99 & 8,38 & 6,18 & 8,11 & 6,78 \\
\hline
\end{tabular}


Uluslararası Yönetim İktisat ve İşletme Dergisi, ICMEB17 Özel Sayısı

Int. Journal of Management Economics and Business, ICMEB17 Special Issue

\begin{tabular}{|c|c|c|c|c|c|c|c|c|}
\hline Genel Ortalama & & $\mathbf{9 , 8 3}$ & 6,3 & 9,37 & 8,8 & 6,79 & 8,82 & 8,35 \\
\hline \multirow{7}{*}{$\begin{array}{c}\text { Ölçek yoğun } \\
\text { sanayiler }\end{array}$} & 21 & 0,04 & 0,01 & 0,01 & 0,03 & 0,49 & 0,29 & 0,33 \\
\hline & 22 & 0,00 & 0,00 & 0,00 & 0,00 & 0,00 & 0,00 & 0,00 \\
\hline & 24 & 0,29 & 0,69 & 0,61 & 1,50 & 0,98 & 0,69 & 0,39 \\
\hline & 25 & 2,72 & 2,20 & 2,85 & 2,88 & 2,50 & 3,21 & 2,71 \\
\hline & 27 & 70,19 & 74,92 & 70,85 & 68,67 & 79,11 & 74,44 & 76,69 \\
\hline & 34 & 0,11 & 0,05 & 0,00 & 0,04 & 0,03 & 0,05 & 0,02 \\
\hline & 35 & 0,30 & 0,00 & 0,01 & 1,49 & 0,22 & 0,32 & 0,46 \\
\hline Sektör Toplam & & 73,65 & $\mathbf{7 7 , 8 7}$ & 74,33 & 74,61 & 83,33 & 79 & 80,6 \\
\hline \multirow{5}{*}{$\begin{array}{c}\text { Emek yoğun } \\
\text { sanayiler }\end{array}$} & 17 & 0,92 & 0,42 & 0,11 & 0,36 & 0,12 & 0,17 & 0,18 \\
\hline & 18 & 2,35 & 2,18 & 1,27 & 2,83 & 1,05 & 1,58 & 1,84 \\
\hline & 19 & 0,01 & 0,07 & 0,17 & 0,21 & 0,16 & 0,39 & 0,47 \\
\hline & 28 & 3,78 & 3,61 & 5,93 & 5,24 & 3,00 & 2,79 & 2,15 \\
\hline & 36 & 1,42 & 0,95 & 1,91 & 1,42 & 1,50 & 2,40 & 2,43 \\
\hline Genel Ortalama & & 8,48 & 7,23 & 9,39 & 10,06 & 5,83 & 7,33 & 7,07 \\
\hline \multirow{5}{*}{$\begin{array}{c}\text { Farklılaştırılmış } \\
\text { ve bilim bazlı } \\
\text { sanayiler }\end{array}$} & 29 & 5,20 & 6,76 & 4,74 & 4,77 & 3,03 & 3,70 & 2,87 \\
\hline & 30 & $\mathrm{Na}$ & 0,00 & 0,00 & 0,00 & 0,00 & na & 0,00 \\
\hline & 31 & 0,22 & 0,15 & 0,07 & 0,13 & 0,06 & 0,22 & 0,22 \\
\hline & 32 & 0,00 & 0,00 & 0,00 & 0,00 & 0,00 & 0,01 & 0,00 \\
\hline & 33 & 0,01 & 0,01 & 0,03 & 0,01 & 0,01 & 0,01 & 0,01 \\
\hline Genel Ortalama & & 1,35 & 1,38 & 0,96 & 0,98 & 0,62 & $\mathbf{0 , 9 8}$ & 0,62 \\
\hline
\end{tabular}

Kaynak: TÜİK verilerinden hareketle tarafımızca hesaplanarak düzenlemiştir. Not: na: ilgili verilerden (ihracat, ithalat) birine ulaşılamadığını ifade eder.

\section{Şekil 8: TR81 Bölgesinin Faktör Yoğunluğuna Göre İhracat Yapısı}

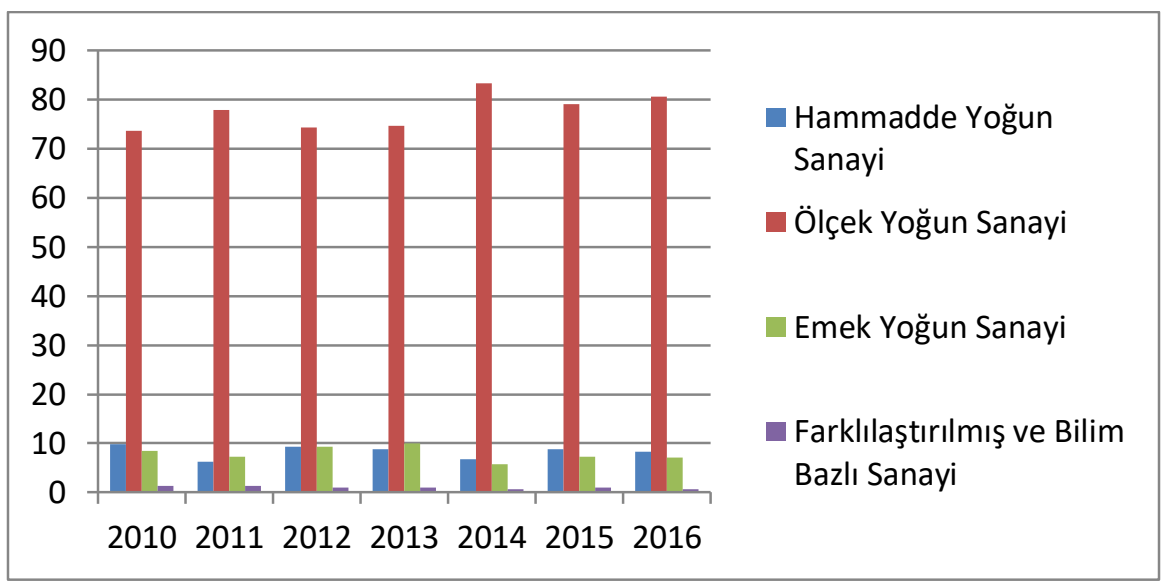

Kaynak: TÜIK verilerinden hareketle tarafimızca hesaplanarak düzenlenmiştir.

Tablo 14'de faktör kullanım yoğunluğuna göre TR81 Bölgesinde ihracatın endüstri-içi ticaret yapısına yer verilmiştir. Endüstri-içi ticaretin ölçümünde literatürde sıklıkla kullanılan Grubel-Lloyd yöntemi kullanılmıştır. $\mathrm{Bu}$ yöntemde $\mathrm{X}_{\mathrm{i}}$ ihracat değeri, $\mathrm{M}_{\mathrm{i}}$ ithalat değerini göstermek üzere endüstri-içi ticaret aşağıdaki gibi ifade edilmektedir (Grubel ve Lloyd, 1975: 21):

$$
B i=\frac{\sum_{i}^{n}[(X i+M i)-(X i-M i)]}{\sum_{i}^{n}(X i+M i)} \text { veya } B i=1-\frac{|X i-M i|}{X i+M i}
$$

Endeks 0 ile 1 arasında değer almakla birlikte, eğer ülke söz konusu malı yalnızca ihraç ya da ithal ediyorsa (endüstri-içi ticaret yoksa) endeks 0 olmaktadır. Eğer aynı malın ithalatı ve ihracatı birbirine eşit ise endeks değeri 1 olmakta ve bu durum endüstri-içi ticaret seviyesinin maksimum olduğunu göstermektedir. Yapılan hesaplamalar neticesinde, bölgede yapılan ticarette endüstri içi ticaretin payının düşük olduğu diğer bir ifadeyle ticaretin endüstriler arası ticaret şeklinde gerçekleştiği görülmektedir. Endüstriler arası ticaret, farklı faktör yoğunluklarına 
Uluslararası Yönetim İktisat ve İşletme Dergisi, ICMEB17 Özel Sayısı

Int. Journal of Management Economics and Business, ICMEB17 Special Issue

bağlı olarak farklı verimlilik düzeylerindeki ürünlerde uzmanlaşma sağlayan ülkeler arasındaki farklı ürünlere dayalı ticarettir.

Tablo 14: Faktör Kullanım Yoğunluğuna Göre TR81 Bölgesi İhracatının Endüstri-İçi Ticaret Yapısı

\begin{tabular}{|c|c|c|c|c|c|c|c|c|}
\hline Yll & \multicolumn{8}{|c|}{ TRB1 Bölgesi } \\
\hline $\begin{array}{c}\text { Faktör } \\
\text { Yoğunluğu }\end{array}$ & Sektör & 2010 & 2011 & 2012 & 2013 & 2014 & 2015 & 2016 \\
\hline \multirow{5}{*}{$\begin{array}{c}\text { Hammadde } \\
\text { yoğun sanayiler }\end{array}$} & 15 & $0,59 *$ & $0,96 *$ & $0,80 *$ & 0,34 & $0,88^{*}$ & $0,63 *$ & $0,68 *$ \\
\hline & 16 & - & - & - & - & - & - & - \\
\hline & 20 & 0,26 & 0,07 & 0,03 & 0,30 & $0,58 *$ & $0,76^{*}$ & 0,29 \\
\hline & 23 & 0,13 & 0,01 & 0,03 & 0,01 & 0,22 & 0,05 & 0,02 \\
\hline & 26 & $0,55^{*}$ & $0,71 *$ & $0,80 *$ & $0,78^{*}$ & $0,87 *$ & $0,72 *$ & $0,77^{*}$ \\
\hline Genel Ortalama & & $\mathbf{0 , 3 8}$ & 0,43 & 0,41 & $\mathbf{0 , 3 5}$ & 0,63 & 0,54 & 0,44 \\
\hline \multirow{7}{*}{$\begin{array}{c}\text { Ölçek yoğun } \\
\text { sanayiler }\end{array}$} & 21 & 0,38 & 0,16 & 0,11 & 0,39 & $0,91 *$ & $0,60 *$ & $0,89 *$ \\
\hline & 22 & 0,05 & 0,01 & 0,28 & 0,18 & 0,11 & 0,11 & 0,03 \\
\hline & 24 & 0,21 & $0,53 *$ & 0,42 & $0,79 *$ & $0,76^{*}$ & 0,45 & 0,27 \\
\hline & 25 & 0,17 & $0,63 *$ & 0,18 & 0,26 & 0,22 & 0,26 & 0,31 \\
\hline & 27 & $0,95 *$ & $0,84 *$ & $0,90^{*}$ & $0,96^{*}$ & $0,88^{*}$ & 0,15 & $0,81 *$ \\
\hline & 34 & 0,31 & $0,60 *$ & 0,12 & 0,44 & $0,62 *$ & $0,91 *$ & $0,72 *$ \\
\hline & 35 & 0,43 & 0,09 & 0,25 & 0,21 & $0,68 *$ & $0,72 *$ & 0,08 \\
\hline Sektör Toplam & & $\mathbf{0 , 3 5}$ & 0,40 & $\mathbf{0 , 3 2}$ & 0,46 & $\mathbf{0 , 5 9}$ & 0,45 & 0,44 \\
\hline \multirow{5}{*}{$\begin{array}{c}\text { Emek yoğun } \\
\text { sanayiler }\end{array}$} & 17 & $0,76^{*}$ & $0,79 *$ & 0,27 & $0,85^{*}$ & $0,51 *$ & 0,41 & $0,62 *$ \\
\hline & 18 & 0,07 & 0,09 & 0,16 & 0,05 & 0,18 & 0,13 & 0,06 \\
\hline & 19 & 0,09 & $0,97 *$ & $0,72 *$ & $0,71 *$ & 0,25 & 0,16 & $0,95^{*}$ \\
\hline & 28 & 0,22 & 0,22 & $0,56^{*}$ & $0,58 *$ & $0,67 *$ & $0,63 *$ & $0,60 *$ \\
\hline & 36 & 0,15 & 0,17 & 0,09 & 0,10 & 0,07 & 0,14 & 0,07 \\
\hline Genel Ortalama & & 0,25 & 0,44 & 0,36 & 0,45 & $\mathbf{0 , 3 3}$ & $\mathbf{0 , 2 9}$ & 0,46 \\
\hline \multirow{5}{*}{$\begin{array}{c}\text { Farklılaştırılmış } \\
\text { ve bilim bazlı } \\
\text { sanayiler }\end{array}$} & 29 & 0,44 & $0,68 *$ & 0,35 & 0,38 & 0,32 & 0,28 & 0,22 \\
\hline & 30 & na & 0,00 & 0,00 & 0,01 & 0,00 & na & 0,03 \\
\hline & 31 & 0,09 & 0,12 & 0,00 & 0,06 & 0,08 & 0,08 & 0,17 \\
\hline & 32 & 0,09 & 0,02 & 0,05 & 0,05 & 0,06 & 0,14 & 0,02 \\
\hline & 33 & 0,01 & 0,02 & 0,05 & 0,01 & 0,02 & 0,02 & 0,02 \\
\hline Genel Ortalama & & 0,15 & 0,16 & 0,09 & $\mathbf{0 , 1 0}$ & 0,09 & 0,13 & 0,09 \\
\hline
\end{tabular}

Kaynak: TÜIKK verilerinden hareketle tarafimızca hesaplanarak düzenlemiştir. Not: na: ilgili verilerden (ihracat, ithalat) birine ulaşılamadığını ifade eder. Literatürde endeks değerinin 0.50 'den fazla olması durumunda endüstri içi ticaretin olduğu kabul edilmektedir. Burada * işareti endüstri içi ticaretin olduğunu göstermektedir.

Şekil 9: Faktör Kullanım Yoğunluğuna Göre TR81 Bölgesi İhracatının Endüstri-İçi Ticaret Yapısı

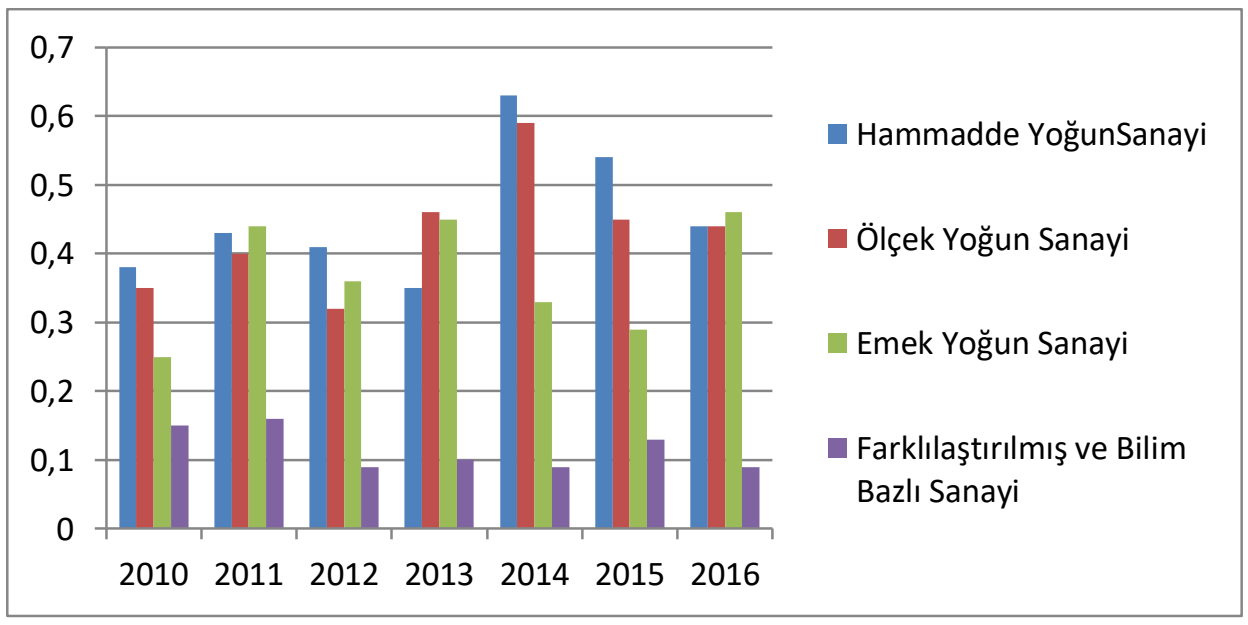

Kaynak: TÜİK verilerinden hareketle tarafimızca hesaplanarak düzenlenmiştir. 


\section{Sonuç}

Bölgesel kalkınma ve dış ticaret arasındaki ilişkinin temeli ihracat tabanlı teorilere dayanmaktadır. Bu teorilere göre, bölgesel kalkınmanın itici faktörü ihracattır. İhracattaki artış, üretimi teşvik edecek, artan üretim de ölçek ekonomileri sayesinde maliyetleri düşürecek böylelikle rekabet ve verimlilik seviyesi artacaktır. Ayrıca üretimdeki artış yatırımlarda artışa yol açarak istihdamı artıracak, işsizliği azaltacaktır.

İstatistikî Bölge Birimleri Sınıflandırmasında Düzey-2 Bölgelerinden biri olan TR81 Bölgesi; Bartın, Karabük ve Zonguldak illerini kapsamaktadır. Batı Karadeniz Bölgesinde yer alan Bölge, 9.493 .04 km² yüzölçümü ile Türkiye yüzölçümünün \%1,21'ini oluşturmaktadır. TRB1 Bölgesindeki illerin rekabetçilik endeksi sıralamasına bakıldığında; Bölgenin rekabet seviyesi düşük ili Bartın'dır. Karabük ve Zonguldak'ın rekabet seviyesi birbirine yakındır. Rekabetçilik endeksi sıralamasına alt başlıklar itibariyle bakıldığında; TR81 Bölgesinde beşeri sermaye; üretim ve ticaret açısından Zonguldak ilinin; yenilikçilik ve yaşanabilirlik açısından Karabük ilinin ön sırada olduğu görülmektedir.

TR81 Bölgesinin dış ticaret yapısını incelendiğinde, bölge ihracatında ve ithalatında en yüksek payın Zonguldak iline ait olduğu görülmektedir. Bölgede ticaretin en az olduğu il ise, Bartın ilidir. TR81 Bölgesinin en fazla ihracat yaptığı ülkeler arasında Romanya, İspanya, İngiltere, Almanya, ABD yer alırken; en fazla ithalat yaptığı ülkeler arasında Ukrayna, Rusya, İsveç ve Brezilya yer almaktadır. Bölgenin en fazla ihraç edilen ürünleri arasında; ana metal sanayi, metalik olmayan diğer mineral ürünler, başka yerde sınıflandırılmamış makine ve teçhizat, metal eşya sanayi (makine ve teçhizatı hariç), plastik ve kauçuk ürünleri bulunmaktadır. En fazla ithal edilen ürünler arasında ise; metal cevherleri, maden kömürü, linyit, ana metal sanayi, atık ve hurdalar, başka yerde sınıflandırılmamış makine ve teçhizat bulunmaktadır. Faktör kulanım yoğunluklarına göre TR81 Bölgesinin ihracatının toplam ihracat içindeki \% payına bakıldığında ise; ölçek yoğun sanayilerin ihracat içindeki payının diğer mal gruplarına göre fazla olduğu görülmektedir. Ayrıca hammadde yoğun sanayiler ile emek yoğun sanayilerin toplam ihracat içindeki paylarının birbirine yakın olduğu görülmektedir. İhracat içindeki en düşük pay ise farklılaştırılmış ve bilim bazlı sanayilerde gerçekleşmektedir. Son olarak faktör kullanım yoğunluğuna göre TR81 Bölgesinde endüstri içi ticaret seviyesinin düşük olduğu görülmektedir. Diğer bir ifadeyle ticaret endüstriler arası ticaret şeklinde gerçekleşmektedir.

\section{Kaynakça}

Brazzel, J., \& Hicks, W. (1968). Exports and regional economic growth: An evaluation of the economic base and staple models. Land Economics, 44(4), 503-509.

Eren, M. V. (2016). Dış ticaretin bölgesel kalkınmadaki rolü: TRB1 bölgesi örneği. UNIDAP Uluslararası Bölgesel Kalkınma Konferansı Bildiriler Kitabı, 465-477.

Grubel, H., \& Lloyd, P. (1975). Intra-Industry trade: The theory and measurement of international trade in differentiated products. London: MacMillan Press.

Örnek, İ., \& Kaplan, M. (2004). Dış Ticaret ve Kalkınma. Kalkınma Ekonomisi Seçme Konular. İçinde S. Taban, M. Kar (ed.), (ss.111-135).

Poveda, A. C. (2011). Economic development and growth in Colombia: An empricial analysis with superefficiency DEA and panel data models. Socio-Economic Planning Sciences, 45, 154-164.

Tüylüoğlu, Ş., \& Çeştepe, H. (2004). Kalkınma Teorilerinin Temelleri ve Gelişimi. İçinde. S. Taban ve M.Kar (ed.), Kalkınma Ekonomisi: Seçme Konular. 1. Baskı. Bursa: Ekin Kitapevi.

TÜİK. (2017). Erişim Tarihi: 11.04.2107, http://www.tuik.gov.tr/Start.do

TÜİK. (2014). Gayri safi katma dĕger, bölgesel sonuçlar, 2004-2012, TÜIK, Ulusal Hesaplar Daire Başkanlı̆̆ Yıllık Hesaplar Grubu, Nisan, Ankara.

URAK. (2016). Illlerin Rekabetçilik Endeksi. Erişim Tarihi: 11.04.2017, http://www.urak.org/urak/ 